\title{
Effects of Phosphorus on In-vitro Seed Germination and Seedling Growth of Brassica rapa L. in Arsenic Condition
}

\author{
Bayezid Mahmud Khan*, Afroza Hasan Afrin, \\ and Mohammad Mosharraf Hossain
}

Institute of Forestry and Environmental Sciences, University of Chittagong, Chittagong-4331, Bangladesh

*Corresponding author Email: bmkhan2004@yahoo.com

https://doi.org/10.12982/CMUJNS.2019.0033

Received: December 4, 2018

Revised: March 22, 2019

Accepted: April 22, 2019

\begin{abstract}
Arsenic (As) is a toxic metalloid widely distributed in the environment posing threat to human health. Enriching the soil with phosphorus $(P)$ in As condition is believed to reduce the uptake of As in plants. But, it is not clear whether this uptake changes affect the growth behaviors of plant or not. Therefore, this study was conducted to determine the efficacy of $P$ in balancing the negative effects of As on Brassica rapa. Seeds of B. rapa were treated with different concentrations of As, with or without addition of P. As exposure hindered seed germination and seedling growth at different magnitudes depending on the level of concentrations. However, addition of $P$ in As solution culture improved the seed germination and seedling growth significantly. Germination were $87 \%$ in $\mathrm{T} 2$ (2 ppm $\mathrm{As}+10 \mathrm{ppm} \mathrm{P}), 78 \%$ in $\mathrm{T} 4$ $(5 \mathrm{ppm} \mathrm{As}+10 \mathrm{ppm} P)$ and $68 \%$ in $\mathrm{T6}(10 \mathrm{ppm} A \mathrm{~s}+10 \mathrm{ppm} P)$ compared to $82 \%$ in $\mathrm{T1}$ (2 ppm As), 73\% in T3 (5 ppm As) and 61\% in T5 (10 ppm As). In treatments T1, T3 and T5, seedling dry biomasses were $26 \mathrm{mg}, 15 \mathrm{mg}$ and 12 mg respectively, which were enhanced to $31 \mathrm{mg}, 21 \mathrm{mg}$ and $16 \mathrm{mg}$ respectively in T2, T4 and T6. Similar trend was also recorded for plumule and radical growth, seedling vigor, sturdiness etc. Therefore, this study recommended the application of $P$ to reduce the negative effects of As on B. rapa in As solution culture and maintains that the results may hold good in the field.
\end{abstract}

Keywords: Brassica rapa, Arsenic, Phosphorus, Germination, Seedling vigor, Sturdiness. 


\section{INTRODUCTION}

The turnip or neep (Brassica rapa L.) is a widely cultivated annual or biennial herbaceous plant of root vegetable belonging to the family Brassicaceae. It is commonly grown in temperate climates, now spread throughout world, including most parts of the tropics for its white, fleshy taproot. Wild forms of the hot turnip and its relatives are found over west Asia and Europe, suggesting their domestication took place somewhere in that area (Susan, 2010; Daniel et al., 2012; Rdnld, 2018). Small, tender varieties of this crop are grown for human consumption, while larger varieties are grown as feed for livestock (Vogl-Lukasser et al., 2007; Slankster et al., 2012). Boiled turnip is 94\% water, $5 \%$ carbohydrates, and $1 \%$ protein, with negligible fat. It also contains iron, calcium, potassium, sodium, and significant amount of vitamin $\mathrm{A}, \mathrm{B}, \mathrm{C}$ and $\mathrm{K}$. It is grown in well drained loam and sandy soils, and needs constant irrigation during the growing season (Susan, 2010; Slankster et al., 2012; Rdnld, 2018).

Elevated concentration of arsenic (As) in surface soil and in plant tissue were reported in Bangladesh unluckily, since As contaminated groundwater has been used for irrigation (Meharg and Rahman, 2003). Areas under turnip cultivation in Bangladesh are prone to the risk. Being a toxic element, As poses serious threats to environment and human health (Leimu and Fischer, 2008; Singh et al., 2015; Babst-Kostecka et al., 2016; Guevara-Garcia et al., 2017; Khan et al., 2018). When crops are grown in As-contaminated soil or irrigated with As-contaminated water, As gets accumulated in the seeds or grain which is becoming an increasingly important problem in many parts of the world (Sanal et al., 2014) as it poses significant risk to animal and human health through soil-crop transfer (Fitz and Wenzel, 2002; Sultana et al., 2015). At high level of As concentrations, yields of a variety of crops shrink significantly (CarbonellBarrachina et al., 1997; Chaturvedi, 2006). Especially, plants with highly waterretentive fruit and vegetable accumulates As in elevated concentrations in their body (Mishra et al., 2014). Moreover, turnip is naturally efficient in preventing As accumulation in their tuber (Vogl-Lukasser et al., 2007; Khan et al., 2011).

On the other hand, phosphorus (P) - an essential plant nutrient that regulates cellular energy transfer, respiration, and photosynthesis (Marschner, 1995) - is a chemical analogue of As (Raghothama, 1999; Khan et al., 2013; Meharg et al., 2014). Therefore, in plant uptake of nutrients, P contests As due to their chemical similarity (Meharg and Macnair, 1992ab; Lee et al., 2003). Consequently, the changes in $\mathrm{P}$ transport mechanisms regulates As uptake (Adriano, 2001) and evidently, the use of $\mathrm{P}$ as a fertilizer modifies the sorption/ desorption of As in soil environment (Peryea, 1998). Although, it is believed that enriching the soil with phosphorus $(\mathrm{P})$ in As condition reduces the uptake 
of As in plants, but it is not clear whether this uptake changes affect the growth behaviors of plant or not. Therefore, this in-vitro study was carried out aiming to determine the efficacy of $\mathrm{P}$ in balancing the negative effects of As on B. rapa with respect to seed germination, seedling growth and biomass production.

\section{MATERIALS AND METHODS}

\section{Study site and period of study}

The experiment was carried out in the laboratory of the Institute of Forestry and Environmental Sciences $\left(91^{\circ} 50^{\prime} \mathrm{E}\right.$ and $\left.22^{\circ} 30^{\prime} \mathrm{N}\right)$, University of Chittagong (IFESCU), Bangladesh. It was conducted between February and June 2017 as the seeds of B. rapa are mostly available in this period in Bangladesh.

\section{Collection of seeds}

Healthy and disease-free seeds were extracted from ripen B. rapa fruits. Seeds were dried in the sunlight before storage in airtight polybags which were then kept at below $4^{\circ} \mathrm{C}$ in refrigerator until use. Seeds of uniform colors and sizes were selected to avoid non-treatment variations (Bonner, 1987). Seeds were tested for viability by using water floating technique before use.

\section{Preparation of Hoagland's and other solutions}

Hoagland's nutrient solution was prepared as stated in Hoagland and Arnon (1950). The solution comprised of $\mathrm{KNO}_{3}, 0.5 \mathrm{~g} \mathrm{~L}^{-1} ; \mathrm{Ca}\left(\mathrm{NO}_{3}\right) .4 \mathrm{H}_{2} \mathrm{O}$, $1.2 \mathrm{~g} \mathrm{~L}^{-1} ; \mathrm{MgSO}_{4} .7 \mathrm{H}_{2} \mathrm{O}, 0.5 \mathrm{~g} \mathrm{~L}^{-1} ; \mathrm{H}_{3} \mathrm{BO}_{3}, 2.8 \mathrm{mg} \mathrm{L}^{-1} ; \mathrm{ZnSO}_{4}, 0.2 \mathrm{mg} \mathrm{L}^{-1}$; $\mathrm{CuSO}_{4}, 0.05 \mathrm{mg} \mathrm{L}^{-1} ; \mathrm{NH}_{4} \mathrm{NO}_{3}, 0.08 \mathrm{mg} \mathrm{L}{ }^{-1} ; \mathrm{MnCl}_{2} .4 \mathrm{H}_{2} \mathrm{O}, 1.8 \mathrm{mg} \mathrm{L} \mathrm{L}^{-1}$; $\mathrm{Na}_{2} \mathrm{MoO}_{4} \cdot 2 \mathrm{H}_{2} \mathrm{O}, 0.12 \mathrm{mg} \mathrm{L}^{-1}$; FeEDTA, $0.02 \mathrm{~g} \mathrm{~L}^{-1}$; in a volume of $1 \mathrm{~L}$. $\mathrm{P}$ was added as $0.07 \mathrm{~g} \mathrm{~L}^{-1}$ of $\mathrm{KH}_{2} \mathrm{PO}_{4}$ for $\mathrm{P}$ treatment and As was added as 0.042 $\mathrm{g} \mathrm{L}^{-1}$ of $\mathrm{Na}_{2} \mathrm{HAsO}_{4} \cdot 7 \mathrm{H}_{2} \mathrm{O}$ for As treatment. The stock solutions were diluted as required for various treatments. The $\mathrm{pH}$ (6.0) of the stock and diluted solutions was adjusted with $1 \mathrm{M} \mathrm{HCl}$ and $1 \mathrm{M} \mathrm{NaOH}$ for all the treatments. Hoagland's solution without $\mathrm{P}$ was common for all the treatments including control.

\section{Experimental design and treatment combinations}

Petri dishes were sterilized by keeping overnight at $200^{\circ} \mathrm{C}$ in convection oven. In each petri dish, 3 layers of moist sterilized filter paper were placed. A Randomized Complete Block Design (RCBD) with 7 treatments with 5 replications was adopted for this experiment. A total of 35 petri dishes were needed for this experiment. The treatment combinations used in the experiment were: 
T0 = Control (Hoagland's solution without $\mathrm{P})$

T1 = 2ppm As (Hoagland's solution without $\mathrm{P}+2 \mathrm{ppm} \mathrm{As}$ )

T2 $=$ 2ppm As + 10ppm P (Hoagland's solution with 10ppm P + 2ppm As)

T3 $=$ 5ppm As (Hoagland's solution without $\mathrm{P}+5 \mathrm{ppm}$ As)

T4 = 5ppm As + 10ppm P (Hoagland's solution with 10ppm P + 5ppm As)

T5 $=$ 10ppm As (Hoagland's solution without $P+10 \mathrm{ppm} \mathrm{As)}$

T6 $=10 \mathrm{ppm}$ As $+10 \mathrm{ppm} \mathbf{P}$ (Hoagland's solution with 10ppm P + 10ppm As)

Seeds were soaked in $0.05 \%$ Mercuric chloride solution for 1 minute for sterilization followed by washing with distilled water and drying before sowing them on petri dishes. In each petri dish, 20 seeds of $B$. rapa were sown and a total of 700 seeds were subjected to 7 different treatments. After sowing the seeds, all the petri dishes were placed in the incubator at $25 \pm 2{ }^{\circ} \mathrm{C}$ temperature. The filter papers of the petri dishes were kept constantly wet at the same level by applying the specific solution of As and $\mathrm{P}$ to the specific petri dishes.

\section{Data recording}

Germination was recorded daily from the date of seed sowing to the last date of germination. The seedlings were allowed to grow for two weeks from the time of seed sowing. After two weeks, five representative seedlings from each treatment were selected to measure growth parameters. The recorded parameters were plumule and radical lengths, collar diameter, fresh and dry weights of plumule and radicle, and number of lateral roots. Plumule and radical were oven dried at $75{ }^{\circ} \mathrm{C}$ for $48 \mathrm{hr}$ to record dry weights. Total height from the collar area to seedling tip of each seedling in each petridish was measured to the nearest $0.1 \mathrm{~cm}$ by using a ruler. Vigor index was calculated according to Abdul-Baki and Anderson (1973) as germination percent $\times$ mean total (plumule and radical) length. Volume index was obtained by multiplying plumule length $(\mathrm{cm})$ with the square of collar diameter $(\mathrm{mm})^{2}$ of the seedlings (Hatchell, 1985). Sturdiness was obtained by dividing plumule length $(\mathrm{cm})$ with collar diameter $(\mathrm{cm})$ of the seedling. The quality index (QI), as developed by Dickson et al., (1960) to quantify seedling morphological quality was calculated as follows:

$$
\mathrm{QI}=\frac{\text { Total seedling dry weight }(\mathrm{g})}{\frac{\text { Plumule length }(\mathrm{cm})}{\text { Collar diameter }(\mathrm{mm})}+\frac{\text { Plumule dry weight }(\mathrm{g})}{\text { Radicle dry weight }(\mathrm{g})}}
$$




\section{Statistical analysis}

SPSS ver.23 was used for statistical analysis of data related to seed germination and seedling growth attributes. The statistical significance $(P<0.05)$ of the differences among the mean values was ascertained by Duncan's multiple range test (DMRT). Different lowercase superscripts letters in a column in the table indicates significant differences.

\section{RESULTS}

\section{Germination percentage}

Germination were $87 \%$ in T2 (2 ppm As $+10 \mathrm{ppm} \mathrm{P}), 78 \%$ in $\mathrm{T} 4$ (5 ppm As $+10 \mathrm{ppm} \mathrm{P)}$ and $68 \%$ in T6 (10 ppm As $+10 \mathrm{ppm} \mathrm{P)} \mathrm{compared} \mathrm{to}$ $82 \%$ in T1 (2 ppm As), $73 \%$ in T3 (5 ppm As) and $61 \%$ in T5 (10 ppm As). The result indicated enhancement of germination rate with the addition of $\mathrm{P}$ in corresponding As solution cultures with decreasing As concentrations (Table 1).

\section{Mean daily and cumulative germination rates}

The highest mean daily germination was $50 \%$ in T2 (2 ppm As +10 ppm $\mathrm{P})$ on the $2^{\text {nd }}$ day followed by $40 \%$ in T4 (5 ppm As $\left.+10 \mathrm{ppm} \mathrm{P}\right)$ on the same day (Figure 1). The highest cumulative germination percent from $2^{\text {nd }}$ day up to the last day of germination ( $9^{\text {th }}$ day) was in T2 (2 ppm As $\left.+10 \mathrm{ppm} \mathrm{P}\right)$, while, the lowest cumulative germination was recorded in T5 (10 ppm As) (Figure 2). The finding indicated the negative impact of increasing As concentration on the progress of germination while addition of $\mathrm{P}$ into the solution showed augmenting effect.

\section{Growth performance}

Plumule lengths were $7.2 \mathrm{~cm}, 5.2 \mathrm{~cm}$ and $3.5 \mathrm{~cm}$, respectively in treatments T1 (2 ppm As), T3 (5 ppm As) and T5 (10 ppm As), while they were $8.3 \mathrm{~cm}, 6.1 \mathrm{~cm}$ and $5.4 \mathrm{~cm}$ in respective treatments T2 (2 ppm As $+10 \mathrm{ppm} \mathrm{P})$, T4 (5 ppm As $+10 \mathrm{ppm} \mathrm{P)}$ and T6 (10 ppm As $+10 \mathrm{ppm} \mathrm{P).} \mathrm{The} \mathrm{outcome}$ clearly demonstrated an increase in plumule length with the addition of $\mathrm{P}$ in decreasing concentrations of As in corresponding As solution cultures (Table 1). Significantly $(P=0.007)$ high $(7.1 \mathrm{~cm})$ and low $(2.4 \mathrm{~cm})$ radical growths were recorded respectively in T2 and in T5 (10 ppm As). In treatments T1 (2 ppm As), T3 (5 ppm As) and T5 (10 ppm As), the number of lateral roots were 21, 13 and 10 respectively, while they were 26,15 and 12 respectively in T2 (2 ppm As +10 ppm P), T4 (5ppm As + 10ppm P) and T6 (10ppm As + 10ppm P). Similar trend was also observed for collar diameter (Table 1). Plumule-radicle ratio was increased 
with the increase of the concentration of As and the increment was further enhanced with the addition of $\mathrm{P}$ in the As solution (Figure 3).

\section{Biomass production}

In treatments T1 (2 ppm As), T3 (5 ppm As) and T5 (10 ppm As), seedling dry biomasses were $26 \mathrm{mg}, 15 \mathrm{mg}$ and $12 \mathrm{mg}$ respectively, which were enhanced to $31 \mathrm{mg}, 21 \mathrm{mg}$ and $16 \mathrm{mg}$ respectively in T2 (2 ppm As $+10 \mathrm{ppm} \mathrm{P})$, T4 (5 ppm As $+10 \mathrm{ppm} \mathrm{P})$ and T6 (10 ppm As $+10 \mathrm{ppm} \mathrm{P})$. Similar trend was evident for fresh biomasses of seedling (Table 2).

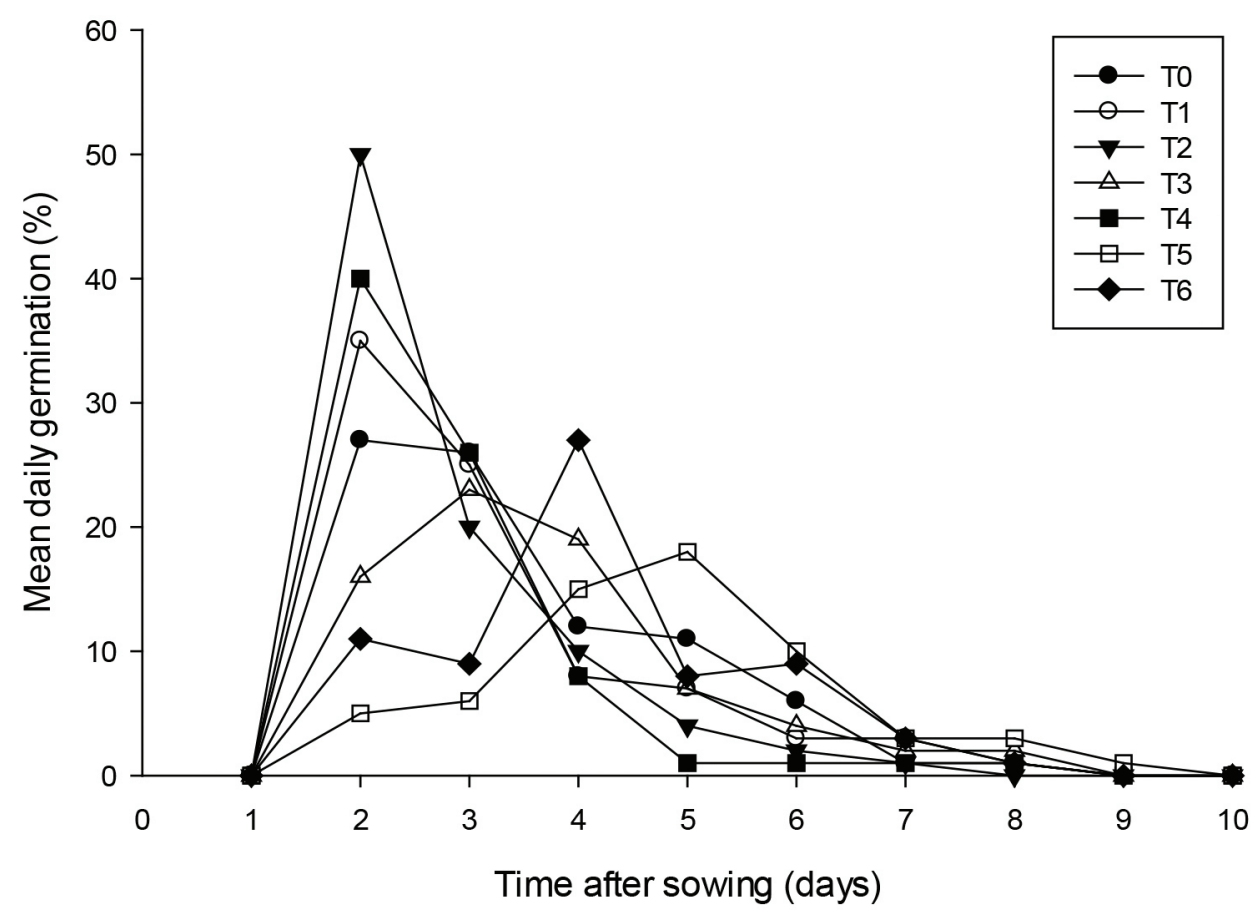

Figure 1. Phosphorus (P) on mean daily germination (\%) of Brassica rapa seeds in arsenic (As) condition.

Note: $\mathrm{T} 0=$ Control, $\mathrm{T} 1=2 \mathrm{ppm} \mathrm{As}, \mathrm{T} 2=2 \mathrm{ppm} \mathrm{As}+10 \mathrm{ppm} \mathrm{P,} \mathrm{T3}=5 \mathrm{ppm} \mathrm{As}$, $\mathrm{T} 4=5 \mathrm{ppm}$ As $+10 \mathrm{ppm} \mathrm{P,} \mathrm{T5}=10 \mathrm{ppm} \mathrm{As,} \mathrm{T6}=10 \mathrm{ppm} \mathrm{As}+10 \mathrm{ppm} \mathrm{P}$. 


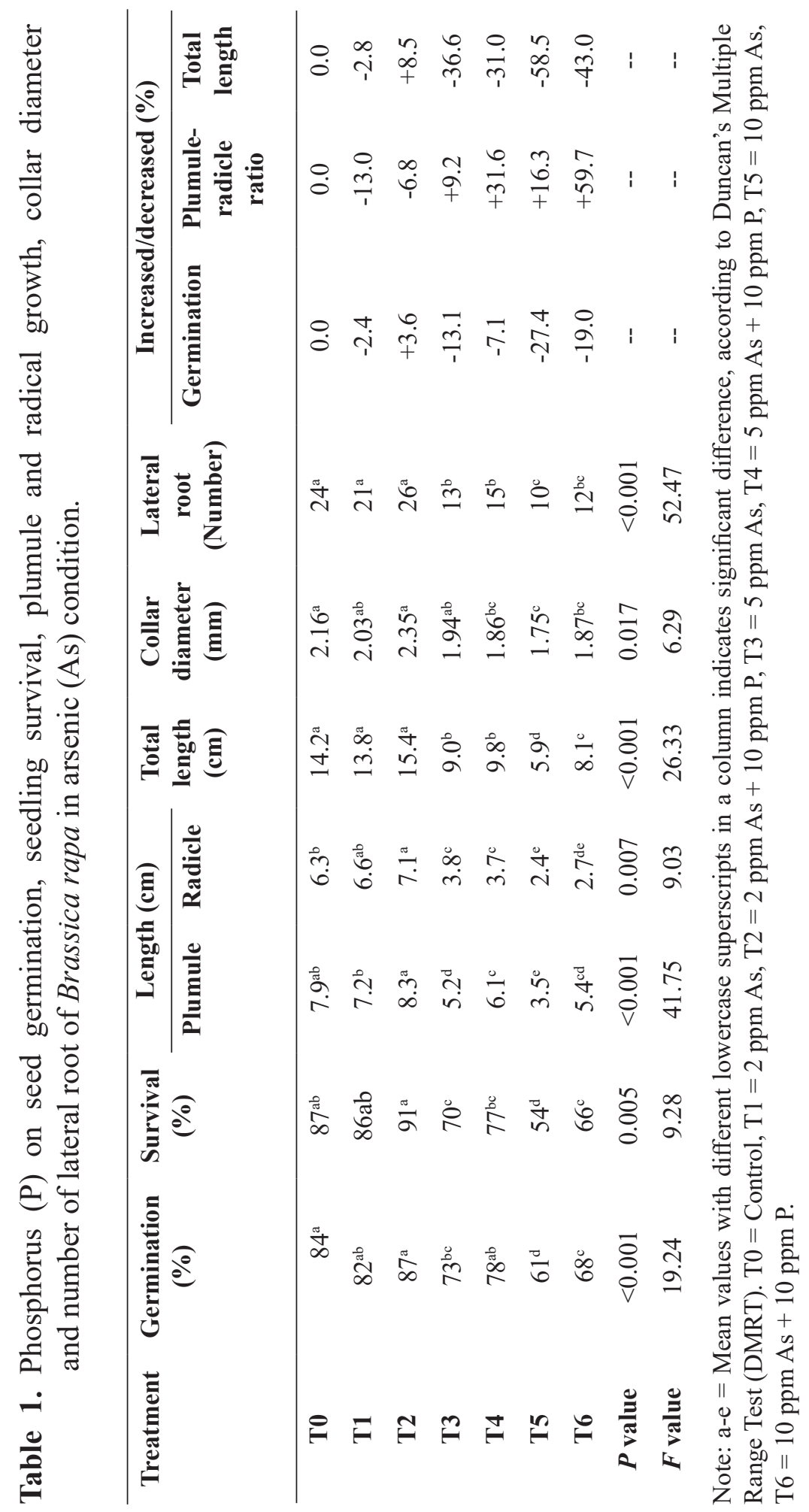




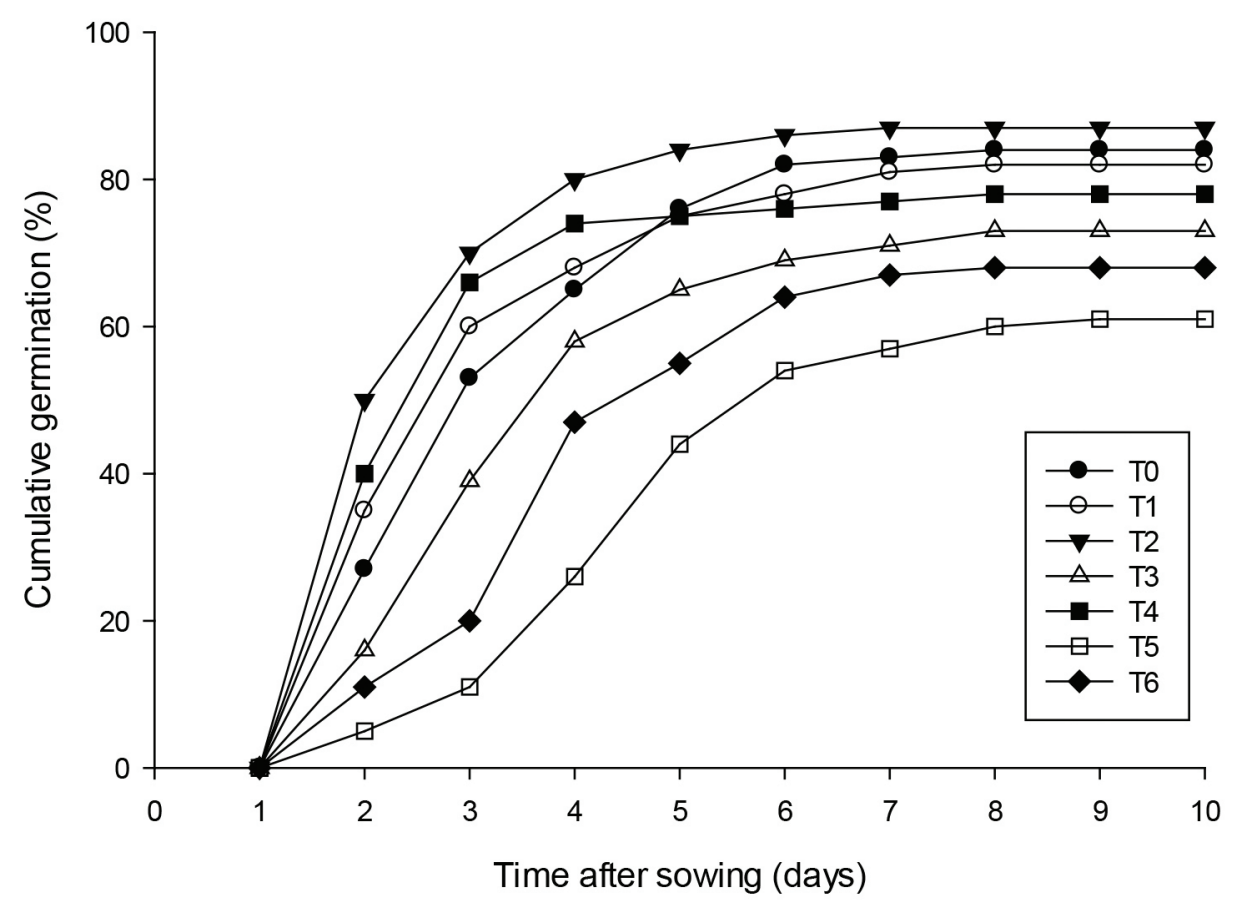

Figure 2. Phosphorus on cumulative germination (\%) of Brassica rapa seeds in arsenic condition.

Note: $\mathrm{T} 0=$ Control, $\mathrm{T} 1=2 \mathrm{ppm} \mathrm{As}, \mathrm{T} 2=2 \mathrm{ppm} \mathrm{As}+10 \mathrm{ppm} \mathrm{P,} \mathrm{T3}=5 \mathrm{ppm} \mathrm{As}$, $\mathrm{T} 4=5 \mathrm{ppm} \mathrm{As}+10 \mathrm{ppm} \mathrm{P}, \mathrm{T} 5=10 \mathrm{ppm} \mathrm{As}, \mathrm{T} 6=10 \mathrm{ppm} \mathrm{As}+10 \mathrm{ppm} \mathrm{P}$. 


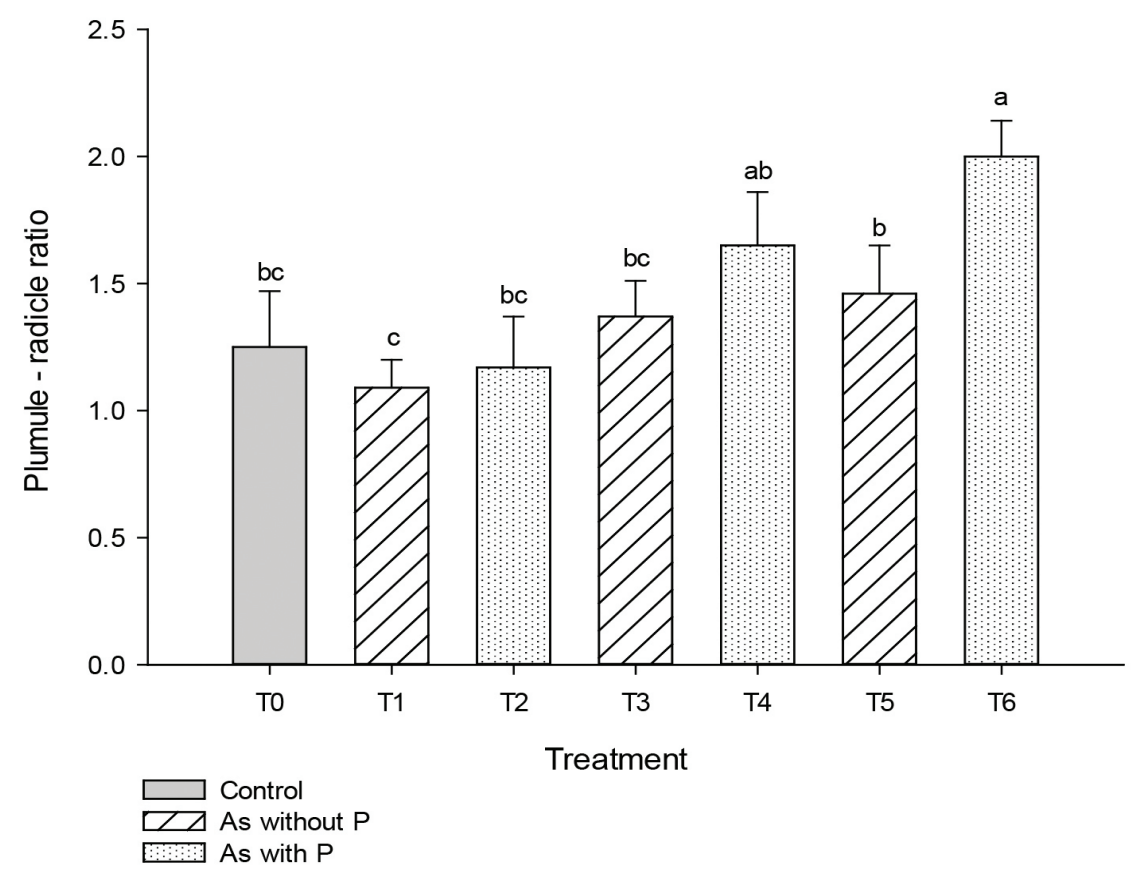

Figure 3. Phosphorus on plumule-radicle ratio of Brassica rapa in arsenic condition.

(Note: $\mathrm{a}-\mathrm{c}=$ Mean values with different lowercase on bars indicates significant difference, according to Duncan's Multiple Range Test. T0 $=$ Control, $\mathrm{T} 1=2$ ppm As, $\mathrm{T} 2=2 \mathrm{ppm} \mathrm{As}+10 \mathrm{ppm} \mathrm{P,} \mathrm{T3}=5 \mathrm{ppm} \mathrm{As}, \mathrm{T} 4=5 \mathrm{ppm} \mathrm{As}+10 \mathrm{ppm}$ $\mathrm{P}, \mathrm{T} 5=10 \mathrm{ppm}$ As, $\mathrm{T} 6=10 \mathrm{ppm}$ As $+10 \mathrm{ppm} \mathrm{P})$. 
Table 2. Phosphorus $(\mathrm{P})$ on fresh and dry biomasses, vigor index and volume index of Brassica rapa in arsenic (As) condition.

\begin{tabular}{cccccccc}
\hline Treatment & \multicolumn{2}{c}{$\begin{array}{c}\text { Seedling } \\
\text { biomass }(\mathbf{m g})\end{array}$} & \multicolumn{2}{c}{ Index } & \multicolumn{2}{c}{ Increased/decreased (\%) } \\
\cline { 2 - 8 } & Fresh & Dry & Vigor & Volume & $\begin{array}{c}\text { Dry } \\
\text { biomass }\end{array}$ & $\begin{array}{c}\text { Vigor } \\
\text { index }\end{array}$ & $\begin{array}{c}\text { Volume } \\
\text { index }\end{array}$ \\
\hline T0 & $205^{\mathrm{ab}}$ & $29 \mathrm{a}$ & $1193^{\mathrm{b}}$ & $36.9^{\mathrm{b}}$ & 0.0 & 0.0 & 0.0 \\
T1 & $169^{\mathrm{b}}$ & $26^{\mathrm{ab}}$ & $1132^{\mathrm{b}}$ & $29.7^{\mathrm{c}}$ & -10.3 & -5.1 & -19.5 \\
T2 & $233^{\mathrm{a}}$ & $31^{\mathrm{a}}$ & $1340^{\mathrm{a}}$ & $45.8^{\mathrm{a}}$ & +6.9 & +12.3 & +24.1 \\
T3 & $102^{\mathrm{e}}$ & $15^{\mathrm{bc}}$ & $657^{\mathrm{d}}$ & $19.6^{\mathrm{de}}$ & -48.3 & -44.9 & -46.9 \\
T4 & $146^{\mathrm{c}}$ & $21^{\mathrm{b}}$ & $764^{\mathrm{cd}}$ & $21.1^{\mathrm{d}}$ & -27.6 & -36.0 & -42.8 \\
T5 & $84^{\mathrm{f}}$ & $12^{\mathrm{c}}$ & $360^{\mathrm{f}}$ & $10.7^{\mathrm{f}}$ & -58.6 & -69.8 & -71.0 \\
T6 & $111^{\mathrm{de}}$ & $16^{\mathrm{bc}}$ & $551^{\mathrm{de}}$ & $18.9^{\mathrm{e}}$ & -44.8 & -53.8 & -48.8 \\
$\boldsymbol{P}$ value & $<0.001$ & 0.013 & $<0.001$ & $<0.001$ & -- & -- & -- \\
$\boldsymbol{F}$ value & 45.3 & 6.65 & 21.84 & 37.59 & -- & -- & -- \\
\hline
\end{tabular}

Note: $\mathrm{a}-\mathrm{f}=$ Mean values with different lowercase superscripts in a column indicates significant difference, according to Duncan's Multiple Range Test (DMRT). T0 $=$ Control, T1 $=2$ ppm As, $\mathrm{T} 2=2 \mathrm{ppm} \mathrm{As}+10 \mathrm{ppm} \mathrm{P,} \mathrm{T3}=5 \mathrm{ppm} \mathrm{As}, \mathrm{T} 4=5 \mathrm{ppm} \mathrm{As}+10 \mathrm{ppm} \mathrm{P,} \mathrm{T5}=10$ ppm As, T6 $=$ 10 ppm As +10 ppm P.

\section{Vigor, volume and quality indices, and sturdiness}

Vigor index were 1,132 in T1 (2 ppm As), 657 in T3 (5 ppm As) and 360 in T5 (10 ppm As), while they were 1,340, 764 and 551 respectively in T2 (2 ppm As + 10 ppm P), T4 (5 ppm As + 10ppm P) and T6 (10 ppm As + 10 ppm P) as shown in table 2 and the differences were significant at $P<0.001$. In treatments T1 (2 ppm As), T3 (5 ppm As) and T5 (10 ppm As), volume index were 29.7, 19.6 and 10.7 respectively compared to $45.8,21.1$ and 18.9 respectively in $\mathrm{T} 2$ $(2 \mathrm{ppm} \mathrm{As}+10 \mathrm{ppm} \mathrm{P})$, T4 (5 ppm As $+10 \mathrm{ppm} \mathrm{P)} \mathrm{and} \mathrm{T6} \mathrm{(10} \mathrm{ppm} \mathrm{As}+10$ ppm P). Quality index values, as shown in figure 4, were 0.0103 in T1 (2 ppm As), 0.008 in T3 (5 ppm As) and 0.0047 in T5 (10 ppm As) in contrast with significantly $(P<0.005)$ higher $0.0112,0.0095$ and 0.0068 respectively in T2 $(2 \mathrm{ppm} \mathrm{As}+10 \mathrm{ppm} \mathrm{P}), \mathrm{T} 4(5 \mathrm{ppm} \mathrm{As}+10 \mathrm{ppm} \mathrm{P})$ and T6 (10 ppm As +10 ppm P). The quality index value was 0.0108 for T0 (control). In treatments T1 (2 ppm As), T3 (5 ppm As) and T5 (10 ppm As), sturdiness were 35.5, 26.8 and 20.0 respectively compared to significantly higher $(P<0.003)$ respective 
values 36.6, 32.8, 28.9 in T2 (2 ppm As $+10 \mathrm{ppm} \mathrm{P})$, T4 (5 ppm As +10 ppm P) and T6 (10 ppm As + $10 \mathrm{ppm} \mathrm{P)} \mathrm{(Figure} \mathrm{5).} \mathrm{All} \mathrm{of} \mathrm{these} \mathrm{observations}$ followed the general trend that higher concentration of As was unfavorable while the addition of $\mathrm{P}$ into As solutions improved the seedling performance.

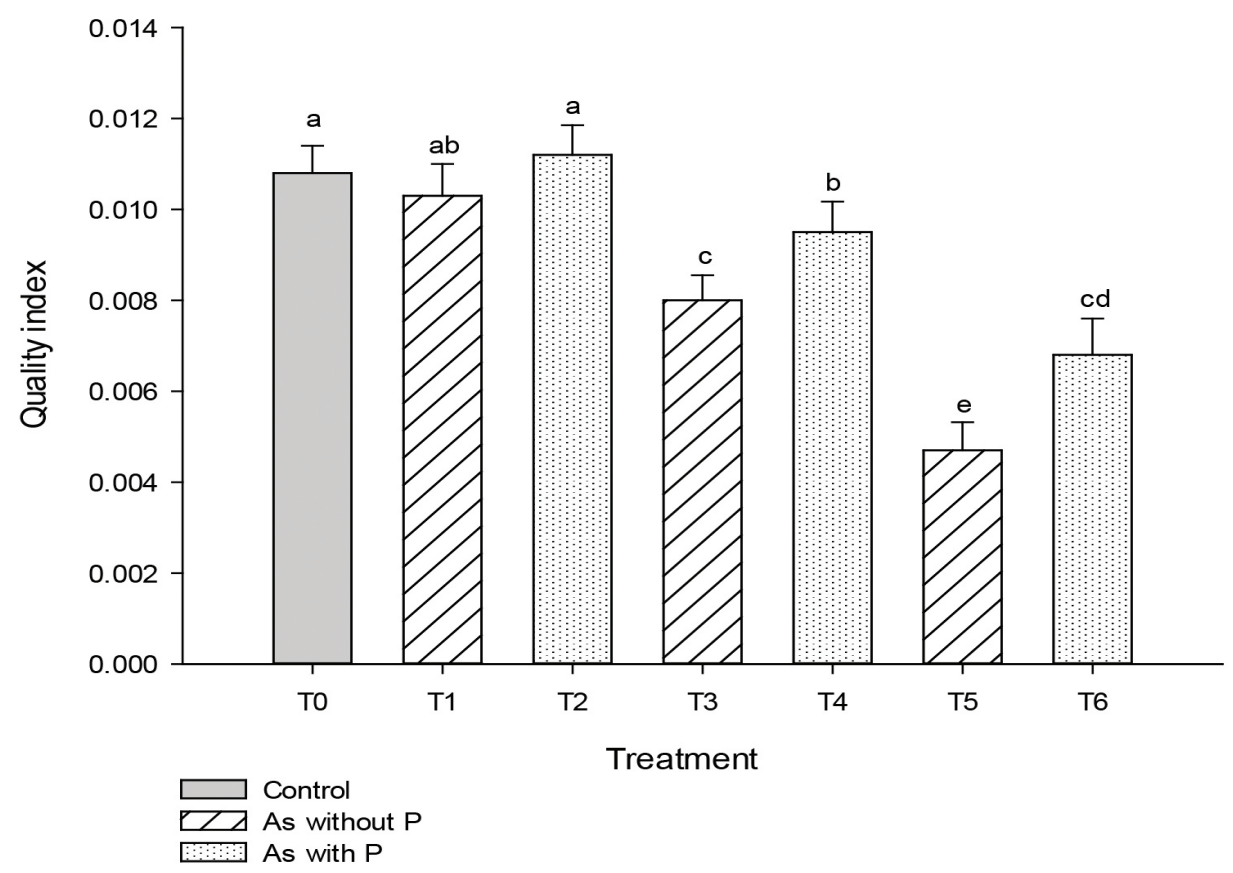

Figure 4. Phosphorus on quality index of Brassica rapa in arsenic condition. Note: $\mathrm{a}-\mathrm{e}=$ Mean values with different lowercase on bars indicates significant difference, according to Duncan's Multiple Range Test. T0 $=$ Control, $\mathrm{T} 1=2 \mathrm{ppm}$ As, $\mathrm{T} 2=2 \mathrm{ppm} \mathrm{As}+10 \mathrm{ppm} \mathrm{P,} \mathrm{T3}=5 \mathrm{ppm}$ As, $\mathrm{T} 4=5 \mathrm{ppm}$ As $+10 \mathrm{ppm} \mathrm{P,} \mathrm{T5}=10$ ppm As, T6 $=10 \mathrm{ppm} \mathrm{As}+10 \mathrm{ppm}$ P. 


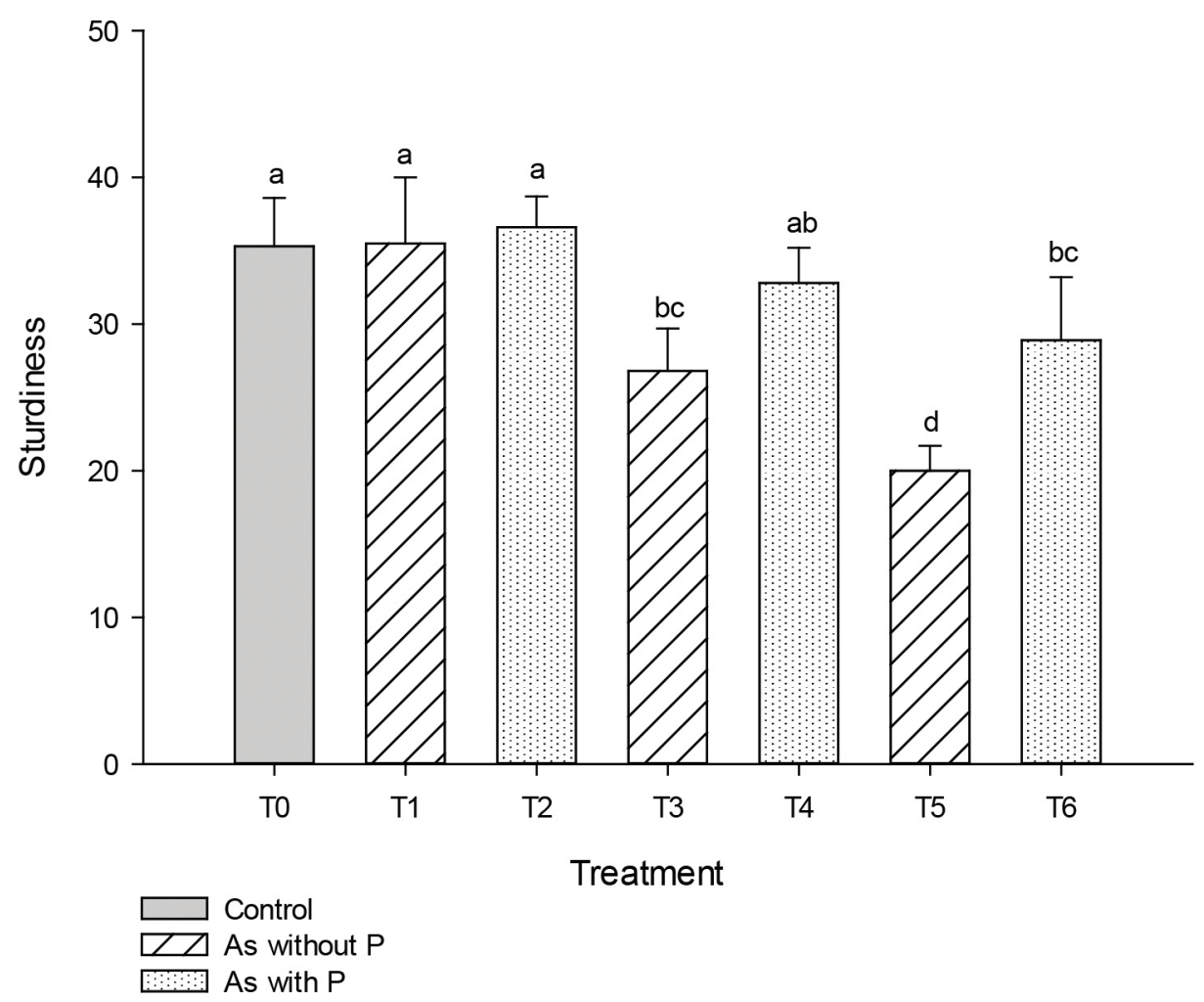

Figure 5. Phosphorus on sturdiness of Brassica rapa in arsenic condition.

Note: $a-d=$ Mean values with different lowercase on bars indicates significant difference, according to Duncan's Multiple Range Test. T0 $=$ Control, $\mathrm{T} 1=2 \mathrm{ppm}$ As, $\mathrm{T} 2=2 \mathrm{ppm} \mathrm{As}+10 \mathrm{ppm} \mathrm{P}, \mathrm{T} 3=5 \mathrm{ppm} \mathrm{As}, \mathrm{T} 4=5 \mathrm{ppm} \mathrm{As}+10 \mathrm{ppm} \mathrm{P}, \mathrm{T} 5=$ $10 \mathrm{ppm} \mathrm{As}, \mathrm{T} 6=10 \mathrm{ppm} \mathrm{As}+10 \mathrm{ppm} \mathrm{P.}$

\section{DISCUSSION}

Accumulation of As mainly occurs in the root system in plants, and in the aboveground organs to a lesser degree (Stoeva et al., 2005; Khan et al., 2013; Meharg et al., 2014). As interrupts the biochemical function of cells and severely impedes different plant metabolic processes including transpiration, respiration, photosynthesis etc., by reacting with proteins and enzymes which culminates in stunted plant growth (Meharg and Hartley-Whitaker, 2002). Plants must take up 
sufficient amount of $\mathrm{P}$ to balance excessive As for the alleviation of As toxicity. The plants react to As exposure by increasing P accumulation (Burlo et al., 1999; Leimu and Fischer, 2008; Khan et al., 2013; Khan et al., 2018).

This in-vitro study noted that, As solution reduces the rate of seed germination, seedling growth and biomass production of seedling of $B$. rapa to varying magnitudes based on the level of As concentrations ( $2 \mathrm{ppm}, 5 \mathrm{ppm}$ and $10 \mathrm{ppm})$. However, addition of $\mathrm{P}(10 \mathrm{ppm})$ in As solution cultures (2 ppm, $5 \mathrm{ppm}$ and $10 \mathrm{ppm}$ respectively) offsetted the harms significantly in comparison to corresponding P-free As solutions. Lou-Hing et al., (2011) also reported that phosphate protects a rice variety- Bala from As toxicity at a lower concentration $(13.3 \mu \mathrm{M})$ of As in the solution culture. Since As is a phosphate analogue, phosphate transporters transports As which results in competition between $\mathrm{P}$ and As for uptake at the level of membrane transport. Accordingly, $\mathrm{P}$ is expected to reduce arsenate influx resulting ultimately into an observed increase in arsenate tolerance under phosphate addition (Ullrich-Eberius et al., 1989; Meharg and Macnair, 1990; Khan et al., 2013; Meharg et al., 2014). Studies, especially in hydroponic environments, have demonstrated that non-resistant plants can be made more resistant to arsenate by raising their $\mathrm{P}$ status, as the $\mathrm{P}$ is taken more effectively compared to arsenate (Meharg and Macnair, 1992b; Lee et al., 2003; Khan et al., 2013). Increasing cytoplasmic phosphate concentration in wheat also demonstrated the role of phosphate against As toxicity (Meharg, 1994). Higher phosphate concentration plays an important role to down-regulation of the arsenate-phosphate plasma membrane transporter and competes with arsenate for biochemical processes where arsenate substitutes for phosphate (Pigna et al., 2009).

\section{CONCLUSION}

Presence of As in solution culture reduced the rate of seed germination, seedling growth and biomass production of $B$. rapa seedling at increasing magnitudes with the increasing of As concentrations. However, the addition of $\mathrm{P}$ in As solution enhanced the performance of seed germination, seedling growth and biomass production of seedling. Hence, application of $\mathrm{P}$ can be recommended in solution culture containing As to reduce the negative impacts of As on $B$. rapa growth in the laboratory. This similar approach might also be applicable in the field conditions. 


\section{REFERENCES}

Abdul-Baki, A., and Anderson, J.D. 1973. Vigor determination in soybean seed by multiple criteria. Crop Science. 13: 630-633. https://doi.org/10.2135/ cropsci1973.0011183X001300060013x

Adriano, D.C. 2001. Trace elements in terrestrial environments: Biogeochemistry, bioavailability and risks of metals. Springer, New York.

Babst-Kostecka, A.A., Waldmann, P., Frerot, H., and Vollenweider, P. 2016. Plant adaptation to metal polluted environments- physiological, morphological, and evolutionary insights from Biscutella laevigata. Environmental and Experimental Botany. 127: 1-13. https://doi.org/ 10.1016/j.envexpbot.2016.03.001

Bonner, F.T. 1987. Importance of seed size in germination and seedling growth. In: Kamra, S.K., and Aylin, R.D. (eds). Proceeding of the International Symposium on Forest Seed Problems in Africa; 1987 Aug 23 - Sep 2; Harare, Zimbabwe. p. 53-61.

Burlo, F., Guijarro, I., Barrachina, A.A.C., and Vlaero, D. 1999. Arsenic species: effects on uptake and accumulation by tomato plants. Journal of Agricultural and Food Chemistry. 47: 1247-1253. https://doi.org/10. 1021/jf9806560

Carbonell-Barrachina, A.A., Burlo, F., Burgos-Hernandez, A., Lopez, E., and Mataix, J. 1997. The influence of arsenite concentration on arsenic accumulation in tomato and bean plants. Scientia Horticulturae. 71: 167-176. https://doi.org/10.1016/S0304-4238(97)00114-3

Chaturvedi, I. 2006. Effects of arsenic concentrations and forms on growth and arsenic uptake and accumulation by Indian Mustard (Brassica juncea L.) genotypes. Journal of Central European Agriculture. 7(1): 31-40.

Daniel, Z., Maria, H., and Ehud, W. 2012. Domestication of plants in the Old World: the origin and spread of domesticated plants in Southwest Asia, Europe, and the Mediterranean Basin. $4^{\text {th }}$ ed. Oxford: Oxford University Press. p.139.

Dickson, A., Leaf, A.L., and Hosner, J.F. 1960. Quality appraisal of white spruce and white pine seedling stock in nurseries. Forestry Chronicle. 36: 10-13. https://doi.org/10.5558/tfc36010-1

Fitz, W.J., and Wenzel, W.W. 2002. Arsenic transformations in the soilrhizosphere-plant system: fundamentals and potential application to phytoremediation. Journal of Biotechnology. 99(3): 259-278. https://doi. org/10.1016/S0168-1656(02)00218-3

Guevara-Garcia, A.A., Lara, F.P., Juarez, L.K., and Herrera-Estrella, L.R. 2017. Heavy metal adaptation. eLS. 1-9. 
Hatchell, G.E. 1985. Proceedings of the $3^{\text {rd }}$ Biological Southern Research Conference. Shoulders E. (ed). Atlanta, Georgia. p. 395-402.

Hoagland, D.R., and Arnon, D.I. 1950. The water culture method for growing plant without soil. California Agricultural Experiment Station Circular. 347: 1-32.

Khan, B.M, Mridha, M.A.U., and Schmidt-Vogt, D. 2011. Environmental Biology (Influence of arbuscular mycorrhizal fungi on the growth of agricultural crops in arsenic amended soil). Lap Lambert Academic Publishing GmbH \& Co. KG.

Khan, B.M., Afrin, A.H., and Hossain, M.M. 2018. Effects of phosphorus on germination and seedling growth of Cucumis sativus $\mathrm{L}$. in arsenic solution culture. International Journal of Rural Development, Environment and Health Research. 2(1): 48-55. https://doi.org/10.22161/ijreh.2.1.6

Khan, B.M., Deacon, C., Meharg, C., Norton, G., Johnson, D., and Meharg, A.A. 2013. A balanced polymorphism in biomass resource allocation controlled by phosphate in grasses screened through arsenate tolerance. Environmental and Experimental Botany. 96: 43-51. https://doi.org/ 10.1016/j.envexpbot.2013.09.008

Lee, D.A., Chen, A., and Schroeder, J.I. 2003. Ars1, an Arabidopsis mutant exhibiting increased tolerance to arsenate and increased phosphate uptake. The Plant Journal. 35(5): 637- 646. https://doi.org/10.1046/ j.1365-313X.2003.01835.x

Leimu, R., and Fischer, M. 2008. A meta-analysis of local adaptation in plants. PLoS ONE. 3(12): e4010. https://doi.org/10.1371/journal.pone.0004010.

Lou-Hing, D., Zhang, B., Price, A.H., and Meharg, A.A. 2011. Effects of phosphate on arsenate and arsenite sensitivity in two rice (Oryza sativa L.) cultivars of different sensitivity. Environmental and Experimental Botany. 72(1): 47-52. https://doi.org/10.1016/j.envexpbot.2010.11.003

Marschner, H. 1995. Mineral nutrition of higher plants. $2^{\text {nd }}$ ed. Academic press, Inc., London.

Meharg A.A. 1994. Ecological impact of major industrial-chemical accident. Reviews on Environmental Contamination and Toxicology. 138: 21-48. https://doi.org/10.1007/978-1-4612-2672-7_2

Meharg, A.A., and Hartley-Whitaker, J. 2002. Arsenic uptake and metabolism in arsenic resistant and nonresistant plant species. New Phytologist. 154(1): 29-43. https://doi.org/10.1046/j.1469-8137.2002.00363.x

Meharg, A.A., and Macnair, M.R. 1990. An altered phosphate uptake system in arsenate tolerant Holcus lanatus L. New Phytologist. 116: 29-35. https:// doi.org/10.1111/j.1469-8137.1990.tb00507.x 
Meharg, A.A., and Macnair, M.R. 1992a. Suppression of the high affinity phosphate uptake system: a mechanism of arsenate tolerance in Holcus lanatus L. Journal of Experimental Botany. 43: 519-524. https://doi. org/10.1093/jxb/43.4.519

Meharg, A.A., and Macnair, M.R. 1992b. Genetic correlation between arsenate tolerance and the rate of arsenate and phosphate uptake in Holcus lanatus L. Heredity. 69: 336-341. https://doi.org/10.1038/hdy.1992.133

Meharg, A.A., and Rahman, M.A. 2003. Arsenic contamination in Bangladesh paddy field soils: implication for rice contribution to arsenic consumption. Environmental Science and Technology. 37: 229-234. https://doi.org/ $10.1021 / \mathrm{es} 0259842$

Meharg, C., Khan, B., Norton, G., Deacon, C., Johnson, D., Reinhardt, R., Huettel, B., and Meharg, A.A. 2014. Trait directed de novo population transcriptome dissects genetic regulation of a balanced polymorphism in phosphorus nutrition/arsenate tolerance in a wild grass Holcus lanatus L. New Phytologist. 201:144-154. https://doi.org/10.1111/nph.12491

Mishra, B.K., Dubey, C.S., Shukla, D.P., Bhattacharya, P., and Usham, A.L. 2014. Concentration of arsenic by selected vegetables cultivated in the Yamuna flood plains (YFP) of Delhi, India. Environmental Earth Sciences. 72(9): 3281-3291. https://10.1007/s12665-014-3232-7

Peryea, F.J. 1998. Phosphate starter fertilizer temporarily enhances soil arsenic uptake by apple trees grown under field conditions. HortScience. 33: 826-829. https://doi.org/10.21273/HORTSCI.33.5.826

Pigna, M., Cozzalino, V., Violante, A., and Meharg, A.A. 2009. Influence of phosphate on the arsenic uptake by wheat (Triticum durum L.) irrigated with arsenic solutions at three different concentrations. Water, Air, and Soil Pollution. 197: 371-380. https://doi.org/10.1007/s11270-0089818-5

Raghothama, K.G. 1999. Phosphate acquisition. Annual Review of Plant Physiology and Plant Molecular Biology. 50: 665-693. https://doi.org/ 10.1146/annurev.arplant.50.1.665

Rdnld, M.W. 2018. Health benefits of turnips. Medical News.

Sanal, F., Şeren, G., and Guuner, U. 2014. Effects of arsenate and arsenite on germination and some physiological attributes of barley (Hordeum vulgare L.). Bulletin of Environmental Contamination and Toxicology. 92(4): 483-489. https://doi.org/10.1007/s00128-014-1214-9

Singh, M., Kumar, J., Singh, S., Singh, V.P., Prasad, S.M., and Singh, M.P.V.V.B. 2015. Adaptation strategies of plants against heavy metal toxicity: a short review. Biochemistry \& Pharmacology 4: 161. https://doi. org/10.4172/2167-0501.1000161 
Slankster, E.E., Chase, J.M., Jones, L.A., and Wendell. D.L. 2012. DNA-Based Genetic Markers for Rapid Cycling Brassica rapa (Fast Plants Type) Designed for the Teaching Laboratory. Frontiers in Plant Science. 3: 118. https://doi.org/10.3389/fpls.2012.00118

Stoeva, N., Berova, M.A., and Zlatev, Z. 2005. Effect of arsenic on some physiological parameters in bean plants. Biologia Plantarum. 49: 293296. https://doi.org/10.1007/s10535-005-3296-z

Sultana, S., Rashid, M.H., and Huq, S.M.I. 2015. Arsenic accumulation in crops in relation to their water requirement. Bangladesh Journal of Scientific Research. 28(2): 171-180. https://doi.org/10.3329/bjsr.v28i2.26789

Susan, S. 2010. “Are 'neeps' swedes or turnips?”. The Guardian.

Ullrich-Eberius, C.I., Sanz, A., and Novacky, A.J. 1989. Evaluation of arsenateand vanadate-associated changes of electrical membrane potential and phosphate transport in Lemna gibba G1. Journal of Experimental Botany. 40(210): 119-128.

Vogl-Lukasser, B., Vogl, C.R., and Reiner, H. 2007. The Turnip (Brassica rapa L. subsp. rapa) in Eastern Tyrol (Lienz district; Austria). Ethnobotany Research \& Applications. 5: 305-317. https://doi.org/10.17348/era.5. $0.305-317$ 